\title{
Cost Results from the 1994 Fernald Characterization Field Demonstration for Uranium-Contaminated Soils
}

Douglas M. Douthat

Robert N. Stewart

Anthony Q. Armstrong

Date Published-April 1995

Prepared for the

Office of Technology Development

(EW 401040 0)

The submitted memuscript has been authored by a contrector of the U.S. Government inder contrect No. DEAC05-840821400. Accordingty, the U.S.

ACO5-B4OA2 1400. Accordingh, tho Us,

Government rotsins i nonexcusivo,

royalty-fice incensec to pubish of reproduce

the publushed form of this contribution. or

blow others to do so. for U.S. Govornmont

\section{Prepared by the}

OAK RIDGE NATIONAL LABORATORY

Oak Ridge, Tennessee 37831-6285

managed by

MARTIN MARIETTA ENERGY SYSTEMS, INC.

for the

U.S. DEPARTMENT OF ENERGY

under contract DE-AC05-84OR21400 


\section{DISCLAIMER}

This report was prepared as an account of work sponsored by an agency of the United States Government. Neither the United States Government nor any agency thereof, nor any of their employees, make any warranty, express or implied, or assumes any legal liability or responsibility for the accuracy, completeness, or usefulness of any information, apparatus, product, or process disclosed, or represents that its use would not infringe privately owned rights. Reference herein to any specific commercial product, process, or service by trade name, trademark, manufacturer, or otherwise does not necessarily constitute or imply its endorsement, recommendation, or favoring by the United States Government or any agency thereof. The views and opinions of authors expressed herein do not necessarily state or reflect those of the United States Government or any agency thereof. 


\section{DISCLAIMER}

Portions of this document may be illegible in electronic image products. Images are produced from the best available original document. 


\section{CONTENTS}

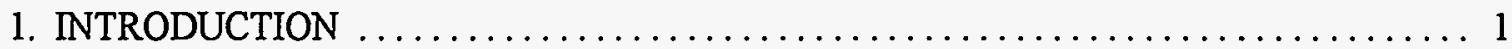

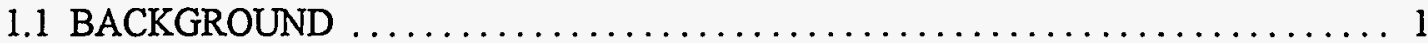

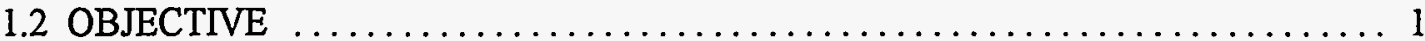

1.3 DESCRIPTION OF FIELD DEMONSTRATION SITE $\ldots \ldots \ldots \ldots \ldots \ldots \ldots \ldots 2$

1.4 ASSUMPTIONS FOR THE COST ESTIMATES $\ldots \ldots \ldots \ldots \ldots \ldots \ldots \ldots \ldots . \ldots \ldots$

2. SOIL CORE SAMPLING AND LABORATORY ANALYSIS $\ldots \ldots \ldots \ldots \ldots \ldots \ldots$

3. TOTAL COST SHEETS FOR FIELD DEMONSTRATION $\ldots \ldots \ldots \ldots \ldots \ldots \ldots$

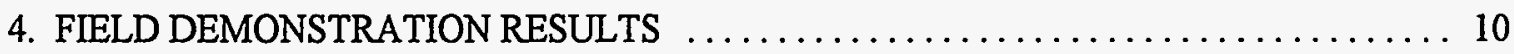

5. SUMMARY OF THE FIELD DEMONSTRATION $\ldots \ldots \ldots \ldots \ldots \ldots \ldots \ldots \ldots$

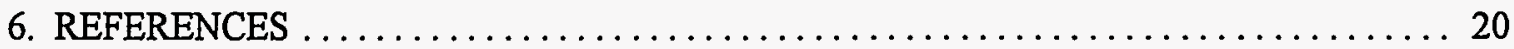




\section{ACRONYMS}

$\begin{array}{ll}\text { DOE } & \text { (United States) Department of Energy } \\ \text { FERMCO } & \text { Fernald Environmental Restoration Management Corporation } \\ \text { Fidler } & \text { Low-energy Scintillation Detector } \\ \text { ICP-MS } & \text { Inductively-Coupled-Plasma Mass Spectrometry } \\ \text { LA-ICP/AES } & \text { Laser Ablation-Inductively Coupled Plasma/Atomic Emission Spectrometry } \\ \text { LANL } & \text { Los Alamos National Laboratory } \\ \text { LRAD } & \text { Long-range Alpha Detector } \\ \text { NaI } & \text { Sodium iodide } \\ \text { ORNL } & \text { Oak Ridge National Laboratory } \\ \text { PNL } & \text { Pacific Northwest Laboratory } \\ \text { SNL } & \text { Sandia National Laboratory } \\ \text { TTP } & \text { Technical Task Plan } \\ \text { XRF } & \text { X-ray Fluorescence }\end{array}$




\section{ACKNOWLEDGMENTS}

This work was sponsored by the U.S. Department of Energy, Office of Technology Development, under the Uranium Soils Integrated Demonstration Program. The authors would like to recognize the support and guidance of Kim Nuhfer (USID coordinator) and Mike Malone (DOE-HQ program manager). In addition, the authors thank Kevin Pylka (Fernald Environmental Restoration Management Corporation) for his assistance in data collection efforts during the field demonstration, as well as his explanations regarding the site characterization activities of each characterization technology during the demonstration. 


\section{INTRODUCTION}

\subsection{BACKGROUND}

One of the principal objectives of the United States Department of Energy (DOE) Office of Technology Development is to develop an optimum integrated system of technologies for removing uranium substances from soil. This system of technologies, through demonstration, must be proven in terms of cost reduction, waste minimization, risk reduction, and user applicability. To evaluate the effectiveness of these technologies, a field demonstration was conducted at the Fernald site in the summer of 1994. Fernald was selected as the host site for the demonstration based on environmental problems stemming from past production of uranium metal for defense-related applications.

The Performance Assessment Task Group at Oak Ridge National Laboratory (ORNL) is responsible for furnishing a systematic evaluation process for the project, providing information to support decision-making for future applications, and establishing the success of each technology. In addition, the Characterization Task Group is responsible for designing and administering a program to address site characterization issues for uranium-contaminated soils. The characterization technologies developed by the Characterization Group are evaluated by the Performance Assessment Group for their adequacy in detecting uranium contamination.

The following six alternative technologies were developed and/or demonstrated by the principal investigators in the Characterization Task Group at the field demonstration: 1) beta scintillation detector by Pacific Northwest Laboratory (PNL), 2) in situ gamma detector by PNL, 3) mobile laser ablationinductively coupled plasma/atomic emission spectrometry (LA-ICP/AES) laboratory by Ames Laboratory, 4) long-range alpha detector (LRAD) by Los Alamos National Laboratory (LANL), 5) passive radon monitoring by ORNL, and 6) electret ion chamber by ORNL. To compare these new alternative technologies to the current state of technology for site characterization, the following traditional field detectors were tested by a Fernald Environmental Restoration Management Corporation (FERMCO) group experienced in site characterization: 1) a sodium-iodide (NaI) detector, 2) a lowenergy scintillation detector (Fidler), and 3) an X-ray fluorescence (XRF) detector. Standard soil core sampling and laboratory analyses were conducted by FERMCO personnel as a baseline condition to verify each characterization technology's ability to accurately characterize uranium contamination in the soil.

\subsection{OBJECTIVE}

The objective of this document is to present the results of each characterization technology's cost effectiveness during the FERMCO field demonstration, as well as describe the methodology used in developing the cost analysis reports. The results from this report will be used in a cost/risk decision model, which will help address such issues as the cost effectiveness of additional sampling, optimal sampling strategies, and uncertainty in predicted contamination at unsampled points. Sandia National Laboratory (SNL) has been tasked to develop and apply the cost/risk decision-making framework under the Technical Task Plan (TTP), "Cost/Risk Performance Assessment of Soil Characterization" (TTP AL231007). In support of this TTP, Performance Assessment Group members developed cost data for use in the cost/risk decision model. 
During the field demonstration, FERMCO personnel were responsible for recording the amount of time required for each group to conduct the following activities associated with their respective characterization technologies: 1) equipment assembly and setup, 2) equipment calibration, 3) site characterization, and 4) equipment decontamination and disassembly/loading for transport. A data base, created by Performance Assessment Group members, included the amount of time spent by each group to complete each of the aforementioned four activities during the field demonstration of each technology. The daily characterization sheets provide the following information for each day the technology was in the field: 1) actual recorded times spent for equipment assembly and setup, equipment calibration, site characterization (data manipulation and processing are included in this activity), and equipment decontamination and disassembly, along with the number of personnel required for each activity; 2) the number of samples collected in the calibration beds; and 3) the number of field samples collected on the sampling grid.

Based on the recorded times to conduct the tasks associated with characterizing the site, as well as assumptions made by the cost estimators, total costs associated with demonstrating each technology during the field demonstration were developed. A breakdown of these costs and a description of the assumptions made to develop these costs are presented in this report. The cost estimates in this report are based strictly on the recorded times from the daily characterization sheets completed by FERMCO personnel during the field demonstration. Therefore, all of the field screening technologies can be equally evaluated from a cost perspective.

\subsection{DESCRIPTION OF FIELD DEMONSTRATION SITE}

The Characterization Task Group developed the sampling plan and schedule for each technology to follow during the field demonstration (Field Demonstration Project Plan 1994). The field demonstration was performed on a subsection of the incinerator area site. Uranium concentrations are believed to range from background to approximately $80 \mathrm{pCi} / \mathrm{g}$. Contamination at this site is primarily a result from emissions created by incineration of uranium-contaminated combustibles. The demonstration was performed on a gridded subsection of the site measuring approximately $126,000 \mathrm{ft}^{2}$. Four calibration beds were created by homogenizing and spiking the beds with uranium-contaminated Fernald soil to yield concentrations of near background (approximately $5 \mathrm{pCi} / \mathrm{g}$ ), 35,100 , and $200 \mathrm{pCi} / \mathrm{g}$. These calibration beds were used to normalize and adjust the field screening instruments to yield more accurate results. Standards plots were created to standardize the detector precision quantification. These plots were surveyed twice a day by personnel operating each characterization technology. The following sample locations were set up on the site grid system: 1) 42 regular grid sample points (at 60-ft spacings), 2) 29 short scale points (at 30-ft spacings), and 3) 18 fine scale points (at 5-ft spacings). Data from these 89 sample locations were collected by each characterization technology for the field demonstration and sent to Performance Assessment Task Group members at SNL, who are responsible for documenting the performance of each characterization technology in measuring uranium concentrations.

\subsection{ASSUMPTIONS FOR THE COST ESTIMATES}

Based on previous experience, factors such as travel, transportation, lodging, and miscellaneous costs associated with the operation of each characterization technology are included in the cost estimates for each technology's performance during the field demonstration. These cost estimates are provided 
in Sect. 3. Along with the personnel charge rates, the number of personnel required to operate each characterization technology varied for the field demonstration. It is important to account for these factors in the estimates since the cost to cover these activities would be included if an interested party requested a bid to conduct site characterization work using one of the characterization technologies. For example, transportation costs vary depending on the technology because some of the technologies can be transported in a company van or truck and others require special considerations in terms of travel to a site, such as the mobile LA-ICP/AES laboratory, which is set up in a 44-ft, fifth-wheel trailer. Transportation costs for this technology will generally be higher than for the other technologies.

The personnel operating the characterization technologies were from different DOE sites and were required to travel varying distances to participate in the field demonstration. Therefore, to compare the technologies from an equal standpoint, an assumption was made that 2 days were required for each group operating the technology to complete a round trip of 500 miles to the Fernald site. Therefore, travel costs and personnel salaries for the 2 travel days were included in the cost estimates for each characterization technology, as shown in Sect. 3. In addition, costs associated with activities such as data processing, data manipulation, and data review/analysis were included in the estimates. Miscellaneous costs such as maintenance costs, operating supplies, and personnel protective equipment associated with each technology were also included in the cost estimates.

\section{SOIL CORE SAMPLING AND LABORATORY ANALYSIS}

Soil core samples were collected at both grid points and the standards plots as an accepted baseline for comparing the performance and cost results of the characterization technologies. A FERMCO group collected the soil samples for the field demonstration. The samples were sent to a laboratory for isotopic analysis. A laboratory procedure entitled Inductively-Coupled-Plasma Mass Spectrometry (ICP-MS) was used to analyze the samples for isotopic results. For the field demonstration, field samples were collected at 85 of the 89 grid sample locations. In addition, duplicate samples were collected at 18 random grid points, resulting in a total of 103 field samples collected for laboratory analysis. Therefore, for the soil sampling and laboratory analysis scenario, 103 field point samples were used to calculate the total labor cost per sample and total cost per sample values.

\section{TOTAL COST SHEETS FOR FIELD DEMONSTRATION}

The following discussion provides an itemized list of the total costs associated with each technology's performance during the field demonstration based on the assumptions discussed in Subsect. 1.4. Labor costs are based on the time the operators of each technology were in the field. The labor required for data manipulation and processing is also included in the labor costs. The lodging and per diem costs shown on the cost sheets in Table 1 are based on the assumption that two personnel are 
Table 1. Cost Sheets for Characterization Technologies

Sodium Iodide Detector

\begin{tabular}{|c|c|c|c|c|c|}
\hline Item & Item Description & Unit & Quantity & Cost/Unit & Total Cost \\
\hline 1 & Transportation Costs & mile & 500.00 & $\$ 0.29$ & $\$ 145$ \\
\hline 2 & Lodging Costs & day & 6.00 & $\$ 62.00$ & $\$ 372$ \\
\hline 3 & Per Diem & day & 8.00 & $\$ 34.00$ & $\$ 272$ \\
\hline 4 & Personnel Travel & hours & 32.00 & $\$ 56.00$ & $\$ 1,792$ \\
\hline \multirow[t]{2}{*}{5} & Equipment Assembly and Set-up & man-hr & 0.38 & $\$ 56.00$ & $\$ 21$ \\
\hline & & man-hr & 0.38 & $\$ 56.00$ & $\$ 21$ \\
\hline \multirow[t]{2}{*}{6} & Equipment Calibration & man-hr & 1.21 & $\$ 56.00$ & $\$ 68$ \\
\hline & & man-hr & 1.21 & $\$ 56.00$ & $\$ 68$ \\
\hline \multirow[t]{2}{*}{7} & Site Characterization & man-hr & 7.42 & $\$ 56.00$ & $\$ 416$ \\
\hline & & man-hr & 7.42 & $\$ 56.00$ & $\$ 416$ \\
\hline \multirow[t]{2}{*}{8} & Equipment Decontamination/Disassembly/etc & man-hr & 0.17 & $\$ 56.00$ & $\$ 10$ \\
\hline & & man-hr & 0.17 & $\$ 56.00$ & $\$ 10$ \\
\hline 9 & Miscellaneous: (Safety boots, Glasses, etc...) & unit & 2.00 & $\$ 50.00$ & $\$ 100$ \\
\hline \multicolumn{2}{|r|}{ Total Cost } & & & & $\$ 3,709$ \\
\hline
\end{tabular}

\section{Fidler Detector}

\begin{tabular}{|c|c|c|c|c|c|}
\hline Item & Item Description & Unit & Quantity & Cost/Unit & Total Cost \\
\hline 1 & Transportation Costs & mile & 500.00 & $\$ 0.29$ & $\$ 145$ \\
\hline 2 & Lodging Costs & day & 10.00 & $\$ 62.00$ & $\$ 620$ \\
\hline 3 & Per Diem & day & 12.00 & $\$ 34.00$ & $\$ 408$ \\
\hline 4 & Personnel Travel & hours & 32.00 & $\$ 56.00$ & $\$ 1,792$ \\
\hline \multirow[t]{2}{*}{4} & Equipment Assembly and Set-up & man-hr & 0.25 & $\$ 56.00$ & $\$ 14$ \\
\hline & & $\operatorname{man}-\mathrm{hr}$ & 0.25 & $\$ 56.00$ & $\$ 14$ \\
\hline \multirow[t]{2}{*}{5} & Equipment Calibration & man-hr & 1.63 & $\$ 56.00$ & $\$ 91$ \\
\hline & & $\operatorname{man}-\mathrm{hr}$ & 1.63 & $\$ 56.00$ & $\$ 91$ \\
\hline \multirow[t]{2}{*}{6} & Site Characterization & $\operatorname{man}-\mathrm{hr}$ & 13.15 & $\$ 56.00$ & $\$ 736$ \\
\hline & & man-hr & 13.15 & $\$ 56.00$ & $\$ 736$ \\
\hline \multirow[t]{2}{*}{7} & Equipment Decontamination/Disassembly/etc & man-hr & 0.21 & $\$ 56.00$ & $\$ 11$ \\
\hline & & man-hr & 0.21 & $\$ 56.00$ & $\$ 11$ \\
\hline 8 & Miscellaneous: (Safety Boots, Glasses...) & unit & 2.00 & $\$ 50.00$ & $\$ 100$ \\
\hline \multicolumn{2}{|r|}{ Total Cost } & & & & $\$ 4,771$ \\
\hline
\end{tabular}


Table 1. (continued)

\section{Electret Ion Chamber}

\begin{tabular}{|c|c|c|c|c|c|}
\hline Item & Item Description & Unit & Quantity & Cost/Unit & Total Cost \\
\hline 1 & Transportation Costs & mile & 500.00 & $\$ 0.29$ & $\$ 145$ \\
\hline 2 & Lodging Costs & day & 12.00 & $\$ 62.00$ & $\$ 744$ \\
\hline 3 & Per Diem & day & 14.00 & $\$ 34.00$ & $\$ 476$ \\
\hline 4 & Personnel Travel & hours & 32.00 & $\$ 100.00$ & $\$ 3,200$ \\
\hline \multirow[t]{2}{*}{5} & Equipment Assembly and Set-up & man-hr & 1.84 & $\$ 100.00$ & $\$ 184$ \\
\hline & & man-hr & 1.84 & $\$ 100.00$ & $\$ 184$ \\
\hline \multirow[t]{2}{*}{6} & Equipment Calibration & man-hr & 2.13 & $\$ 100.00$ & $\$ 213$ \\
\hline & & man-hr & 2.13 & $\$ 100.00$ & $\$ 213$ \\
\hline \multirow[t]{2}{*}{7} & Site Characterization & man-hr & 9.33 & $\$ 100.00$ & $\$ 933$ \\
\hline & & man-hr & 9.33 & $\$ 100.00$ & $\$ 933$ \\
\hline \multirow[t]{2}{*}{8} & Equipment Decontamination/Disassembly/etc & man-hr & 0.64 & $\$ 100.00$ & $\$ 64$ \\
\hline & & man-hr & 0.64 & $\$ 100.00$ & $\$ 64$ \\
\hline \multirow[t]{3}{*}{9} & Miscellaneous: Volt Meter Replacement & day & 5 & $\$ 5.00$ & $\$ 25$ \\
\hline & Review/Analyize data sheets & hours & 8 & $\$ 100.00$ & $\$ 800$ \\
\hline & Cost to buy and process detectors & day & 116 & $\$ 10.00$ & $\$ 1,160$ \\
\hline \multicolumn{2}{|r|}{ Total Cost } & & & & $\$ 9,337$ \\
\hline
\end{tabular}

\section{X-Ray Fluorescence (XRF) Detector}

\begin{tabular}{|c|c|c|c|c|c|}
\hline Item & Item Description & Unit & Quantity & Cost/Unit & Total Cost \\
\hline 1 & Transportation Costs & mile & 500.00 & 50.29 & $\$ 145$ \\
\hline 2 & Lodging Costs & day & 24.00 & $\$ 62.00$ & $\$ 1,488$ \\
\hline 3 & Per Diem & day & 26.00 & $\$ 34.00$ & $\$ 884$ \\
\hline 4 & Personnel Travel & hours & 32.00 & $\$ 56.00$ & $\$ 1,792$ \\
\hline \multirow{2}{*}{5} & Equipment Assembly and Set-up & man-hr & 4.75 & $\$ 56.00$ & $\$ 266$ \\
\hline & & man-hr & 4.75 & $\$ 56.00$ & $\$ 266$ \\
\hline \multirow[t]{2}{*}{6} & Equipment Calibration & man-hr & 3.99 & $\$ 56.00$ & $\$ 223$ \\
\hline & & man-hr & 3.99 & $\$ 56.00$ & $\$ 223$ \\
\hline \multirow[t]{2}{*}{7} & Site Characterization & man-hr & 33.02 & $\$ 56.00$ & $\$ 1,849$ \\
\hline & & man-hr & 33.02 & $\$ 56.00$ & $\$ 1,849$ \\
\hline \multirow[t]{2}{*}{8} & Equipment Decontamination/Disassembly/etc & man-hr & 0.68 & $\$ 56.00$ & $\$ 38$ \\
\hline & & $\operatorname{man}-\mathrm{hr}$ & 0.68 & $\$ 56.00$ & $\$ 38$ \\
\hline \multirow[t]{8}{*}{9} & Miscellaneous: Personnel Protective Equipment & unit & 2.00 & $\$ 50.00$ & $\$ 100$ \\
\hline & Window Assembly & day & 11.00 & $\$ 4.00$ & $\$ 44$ \\
\hline & Lithium batteries & day & 11.00 & $\$ 0.39$ & $\$ 4$ \\
\hline & Cd source & day & 11.00 & $\$ 19.25$ & $\$ 212$ \\
\hline & Vinyl tape & roll & 1.00 & $\$ 2.20$ & $\$ 2$ \\
\hline & X-ray Mylar film & roll & 1.00 & $\$ 40.00$ & $\$ 40$ \\
\hline & 31mm double open X-Ray Cell & 100 cells & 1.00 & $\$ 63.00$ & $\$ 63$ \\
\hline & Window Assembly & day & 1.00 & $\$ 60.92$ & $\$ 61$ \\
\hline
\end{tabular}


Table 1. (continued)

\section{Passive Radon Monitoring}

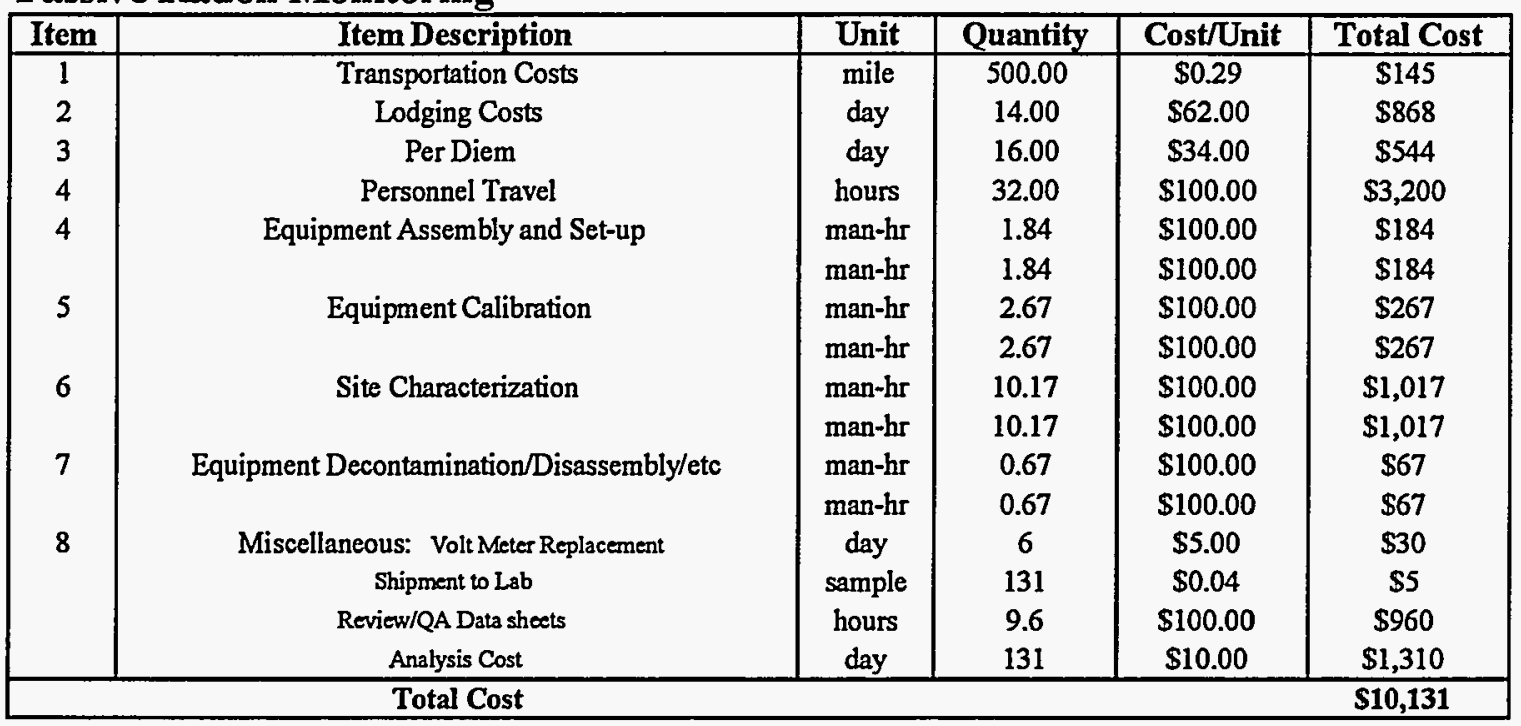

In Situ Gamma Detector (High Set-up)

\begin{tabular}{|c|c|c|c|c|c|}
\hline Item & Item Description & Unit & Quantity & Cost/Unit & Total Cost \\
\hline 1 & Transportation Costs & mile & 500 & $\$ 0.25$ & $\$ 125$ \\
\hline 2 & Lodging Costs & day & 16 & $\$ 62.00$ & $\$ 992$ \\
\hline 3 & Per Diem & day & 18 & $\$ 34.00$ & $\$ 612$ \\
\hline \multirow[t]{2}{*}{4} & Personnel Travel & hours & 16 & $\$ 90.00$ & $\$ 1,440$ \\
\hline & & hours & 16 & $\$ 110.00$ & $\$ 1,760$ \\
\hline \multirow[t]{2}{*}{5} & Equipment Assembly and Set-up & man-hr & 5 & $\$ 90.00$ & $\$ 450$ \\
\hline & & man-hr & 5 & $\$ 110.00$ & $\$ 550$ \\
\hline \multirow[t]{2}{*}{6} & Equipment Calibration & man-hr & 1.58 & $\$ 90.00$ & $\$ 142$ \\
\hline & & man-hr & 1.58 & $\$ 110.00$ & $\$ 174$ \\
\hline \multirow[t]{2}{*}{7} & Site Characterization & man-hr & 32.09 & $\$ 90.00$ & $\$ 2,888$ \\
\hline & & man-hr & 32.09 & $\$ 110.00$ & $\$ 3,530$ \\
\hline \multirow[t]{2}{*}{8} & Equipment Decontamination/Disassembly/etc & man-hr & 1.75 & $\$ 90.00$ & $\$ 158$ \\
\hline & & man-hr & 1.75 & $\$ 110.00$ & $\$ 193$ \\
\hline \multirow[t]{2}{*}{9} & Miscellaneous: Gloves, face shield, safety glasses & trip & 2 & $\$ 50.00$ & $\$ 100$ \\
\hline & Generator Fuel and Liquid Nitrogen & day & 7 & $\$ 10.00$ & $\$ 70$ \\
\hline & Total Cost & & & & $\$ 13,183$ \\
\hline
\end{tabular}


Table 1. (continued)

In Situ Gamma Detector (Low Set-up)

\begin{tabular}{|c|c|c|c|c|c|}
\hline Item & Item Description & Unit & Quantity & Cost/Unit & Total Cost \\
\hline 1 & Transportation Costs & mile & 500 & $\$ 0.25$ & $\$ 125$ \\
\hline 2 & Lodging Costs & day & 16 & $\$ 62.00$ & $\$ 992$ \\
\hline 3 & Per Diem & day & 18 & $\$ 34.00$ & $\$ 612$ \\
\hline \multirow[t]{2}{*}{4} & Personnel Travel & day & 16 & $\$ 90.00$ & $\$ 1,440$ \\
\hline & & hours & 16 & $\$ 110.00$ & $\$ 1,760$ \\
\hline \multirow[t]{2}{*}{5} & Equipment Assembly and Set-up & man-hr & 5.25 & $\$ 90.00$ & $\$ 473$ \\
\hline & & man-hr & 5.25 & $\$ 110.00$ & $\$ 578$ \\
\hline \multirow[t]{2}{*}{6} & Equipment Calibration & man-hr & 1.58 & $\$ 90.00$ & $\$ 142$ \\
\hline & & man-hr & 1.58 & $\$ 110.00$ & $\$ 174$ \\
\hline \multirow[t]{2}{*}{7} & Site Characterization & man-hr & 34.02 & $\$ 90.00$ & $\$ 3,062$ \\
\hline & & man-hr & 34.02 & $\$ 110.00$ & $\$ 3,742$ \\
\hline \multirow[t]{2}{*}{8} & Equipment Decontamination/Disassembly/etc & man-hr & 2 & $\$ 90.00$ & $\$ 180$ \\
\hline & & man-hr & 2 & $\$ 110.00$ & $\$ 220$ \\
\hline \multirow[t]{2}{*}{9} & Miscellaneous: Gloves, face shield, safety glasses & trip & 2 & $\$ 50.00$ & $\$ 100$ \\
\hline & Generator Fuel and Liquid Nitrogen & day & 7 & $\$ 10.00$ & $\$ 70$ \\
\hline \multicolumn{2}{|r|}{ Total Cost } & & & & $\$ 13,669$ \\
\hline
\end{tabular}

Long-Range Alpha Detector

\begin{tabular}{|c|c|c|c|c|c|}
\hline Item & Item Description & Unit & Quantity & Cost/Unit & Total Cost \\
\hline 1 & Transportation Costs & mile & 500.00 & \$0.24 & $\$ 120$ \\
\hline 2 & Lodging Costs & day & 14.00 & $\$ 62.00$ & $\$ 868$ \\
\hline 3 & Per Diem & day & 16.00 & $\$ 34.00$ & $\$ 544$ \\
\hline \multirow[t]{2}{*}{4} & \multirow[t]{2}{*}{ Personnel Travel } & hours & 16.00 & $\$ 113.00$ & $\$ 1,808$ \\
\hline & & hours & 16.00 & $\$ 150.00$ & $\$ 2,400$ \\
\hline \multirow[t]{2}{*}{4} & \multirow[t]{2}{*}{ Equipment Assembly and Set-up } & man-hr & 1.57 & $\$ 113.00$ & $\$ 177$ \\
\hline & & man-hr & 1.57 & $\$ 150.00$ & $\$ 236$ \\
\hline \multirow[t]{2}{*}{5} & \multirow[t]{2}{*}{ Equipment Calibration } & man-hr & 2.50 & $\$ 113.00$ & $\$ 283$ \\
\hline & & $\operatorname{man}-\mathrm{hr}$ & 2.50 & $\$ 150.00$ & $\$ 375$ \\
\hline \multirow[t]{2}{*}{6} & \multirow[t]{2}{*}{ Site Characterization } & man-hr & 24.85 & $\$ 113.00$ & $\$ 2,807$ \\
\hline & & man-hr & 24.85 & $\$ 150.00$ & $\$ 3,727$ \\
\hline \multirow[t]{2}{*}{7} & \multirow[t]{2}{*}{ Equipment Decontamination/Disassembly/etc } & man-hr & 1.22 & $\$ 113.00$ & $\$ 138$ \\
\hline & & man-hr & 1.22 & $\$ 150.00$ & $\$ 183$ \\
\hline \multirow[t]{3}{*}{8} & Miscellaneous: Safety Shoes and sunscreen & unit & 2.00 & $\$ 110.00$ & $\$ 220$ \\
\hline & Cost to Ship LRAD & trip & 1.00 & $\$ 1,420.00$ & $\$ 1,420$ \\
\hline & Diesel fuel and $A C$ power to charge batteries & day & 6.00 & $\$ 10.00$ & $\$ 60$ \\
\hline
\end{tabular}


Table 1. (continued)

Beta Scintillation Detector
\begin{tabular}{|c|c|c|c|c|c|}
\hline Item & Item Description & Unit & Quantity & Cost/Unit & Total Cost \\
\hline 1 & Transportation Costs & mile & 500.00 & $\$ 0.25$ & $\$ 125$ \\
2 & Lodging Costs & day & 14.00 & $\$ 62.00$ & $\$ 868$ \\
3 & Per Diem & day & 16.00 & $\$ 34.00$ & $\$ 544$ \\
4 & Personnel Travel & hours & 16.00 & $\$ 90.00$ & $\$ 1,440$ \\
& hours & 16.00 & $\$ 100.00$ & $\$ 1,600$ \\
4 & Equipment Assembly and Set-up & man-hr & 4.22 & $\$ 90.00$ & $\$ 380$ \\
& & man-hr & 4.22 & $\$ 100.00$ & $\$ 422$ \\
5 & Equipment Calibration & man-hr & 6.63 & $\$ 90.00$ & $\$ 597$ \\
& man-hr & 6.63 & $\$ 100.00$ & $\$ 663$ \\
6 & Site Characterization & man-hr & 42.56 & $\$ 90.00$ & $\$ 3,830$ \\
& & man-hr & 42.56 & $\$ 100.00$ & $\$ 4,256$ \\
7 & Equipment Decontamination/Disassembly/etc & man-hr & 1.48 & $\$ 90.00$ & $\$ 133$ \\
& & man-hr & 1.48 & $\$ 100.00$ & $\$ 148$ \\
8 & day & 6.00 & $\$ 10.00$ & $\$ 60$ \\
& Miscellaneous: (Generator Fuel) & day & 8.00 & $\$ 40.75$ & $\$ 326$ \\
\hline \multicolumn{2}{|l|}{ Van Rental } & \multicolumn{3}{|l}{$\$ 15,391$} \\
\hline
\end{tabular}


Table 1. (continued)

\begin{tabular}{|c|c|c|c|c|c|}
\hline Item & Item Description & Unit & Quantity & Cost/Unit & Total Cost \\
\hline 1 & Transportation Costs & mile & 500.00 & $\$ 0.29$ & $\$ 145$ \\
\hline 2 & Lodging Costs & day & 18.00 & $\$ 62.00$ & $\$ 1,116$ \\
\hline 3 & Per Diem & day & 21.00 & $\$ 34.00$ & $\$ 714$ \\
\hline 4 & Personnel Travel & hours & 48.00 & $\$ 56.00$ & $\$ 2,688$ \\
\hline \multirow[t]{2}{*}{5} & Equipment Assembly and Set-up & man-hr & 0.00 & $\$ 56.00$ & $\$ 0$ \\
\hline & & man-hr & 0.00 & $\$ 56.00$ & \$o \\
\hline \multirow[t]{2}{*}{6} & Equipment Calibration & man-hr & 0.00 & $\$ 56.00$ & \$o \\
\hline & & man-hr & 0.00 & $\$ 56.00$ & \$o \\
\hline \multirow[t]{2}{*}{7} & Site Characterization & man-hr & 101.00 & $\$ 56.00$ & $\$ 5,656$ \\
\hline & & man-hr & 0.00 & $\$ 56.00$ & so \\
\hline \multirow[t]{2}{*}{8} & Equipment Decontamination/Disassembly/etc & man-hr & 0.00 & $\$ 56.00$ & so \\
\hline & & man-hr & 0.00 & $\$ 56.00$ & So \\
\hline 9 & $\begin{array}{l}\text { Laboratory Analys1: } \\
\text { ICP-Mass Spectrometry: isotopic analysis }\end{array}$ & sample & 103.00 & $\$ 200.00$ & $\$ 20,600$ \\
\hline 10 & Personnel Monitoring, Health \& Safety Issues & man-hr & 56.00 & $\$ 56.00$ & $\$ 3,136$ \\
\hline 11 & Miscellaneous: (boots, glasses, coolers, ice, etc..) & unit & 1.00 & $\$ 1,000.00$ & $\$ 1,000$ \\
\hline \multicolumn{5}{|c|}{ Total Cost } & $\$ 35,055$ \\
\hline
\end{tabular}

Mobile LA-ICP-AES Laboratory

\begin{tabular}{|c|c|c|c|c|c|}
\hline Item & Item Description & Unit & Quantity & Cost/Unit & Total Cost \\
\hline 1 & Transportation Costs & mile & 500.00 & $\$ 1.05$ & $\$ 525$ \\
2 & Lodging Costs & day & 40.00 & $\$ 62.00$ & $\$ 2,480$ \\
3 & Per Diem & day & 44.00 & $\$ 34.00$ & $\$ 1,496$ \\
4 & Personnel Travel & hours & 64.00 & $\$ 50.00$ & $\$ 3,200$ \\
5 & Equipment Assembly and Set-up & man-hr & 81.20 & $\$ 50.00$ & $\$ 4,060$ \\
6 & Equipment Calibration & man-hr & 1.00 & $\$ 50.00$ & $\$ 50$ \\
7 & Site Characterization & man-hr & 187.08 & $\$ 50.00$ & $\$ 9,354$ \\
8 & Equipment Decontamination/Disassembly/etc & man-hr & 14.00 & $\$ 50.00$ & $\$ 700$ \\
9 & Miscellaneous: Generator Fuel & day & 9.00 & $\$ 25.00$ & $\$ 225$ \\
& Maintenance Cost & day & 9.00 & $\$ 50.00$ & $\$ 450$ \\
\hline \multicolumn{2}{|r|}{ Total Cost } & & & & $\$ 22,540$ \\
\hline
\end{tabular}


required to operate each technology, with the exception of the mobile LA-ICP/AES laboratory, which required four personnel. The number of personnel required for each task (equipment setup, calibration, etc.) was recorded on the daily characterization sheets by FERMCO personnel. The charge rates for the personnel operating the characterization technologies during the field demonstration varied significantly. The charge rate for personnel ranged from $\$ 50$ per hour for the technicians operating the mobile LAICP/AES laboratory to $\$ 150$ per hour for the scientist operating the long-range alpha detector. The labor costs for each of the tasks associated with the collection of data for each of the technologies demonstrated during the field demonstration are shown on the cost sheets presented in Table 1 . In addition to travel costs and labor costs, miscellaneous costs such as operating supplies and protective equipment were also included in the cost estimates.

\section{FIELD DEMONSTRATION RESULTS}

The field demonstration results for each characterization technology are shown in the pie charts presented in Fig. 1 and the bar graphs provided in Fig. 2. The pie charts provide the number of manhours required for each characterization technology to complete the following activities during the field demonstration: 1) equipment assembly and setup, 2) equipment calibration, 3) site characterization (sampling), and 4) equipment decontamination and disassembly/loading for transport. Although the actual number of hours spent for site characterization varied considerably between technologies, the percentage of time spent for site characterization as a percentage of the total time spent during the demonstration was similar for all of the technologies. As shown in Fig. 1, the majority of the time spent by each technology during the demonstration was used to complete the actual site characterization activities. In general, the pie charts look fairly similar in terms of shading for each activity. However, one exception is that the assembly time and calibration time for the mobile LA-ICP/AES laboratory do not seem to agree with these respective tasks for the other technologies. The assembly time appears high and the calibration time appears to be low, especially when compared to the other technologies.

The bar graphs shown in Fig. 2 also provide the following results from the field demonstration for each characterization technology: 1) the total labor cost associated with equipment assembly and setup, equipment calibration, site characterization, and equipment decontamination and disassembly; 2) the total costs associated with the operation of each technology during the field demonstration; 3) the labor cost per field sample collected; 4) the total cost per field sample collected; 5) the number of days required to collect the field samples; and 6) the total number of man-hours required to complete the field demonstration. To derive the labor cost per sample and the total cost per sample, the respective cost values are divided by the actual number of field samples collected during the field demonstration. Although field data were collected at 89 locations on the sampling grid, many of the characterization technologies actually collected data at a certain location more than once, resulting in a collection of greater than 89 field samples. However, the mobile LA-ICP/AES laboratory crew collected only 83 field samples. In addition, the in situ gamma detector technology collected 88 samples in the low setup and 85 samples in the high setup.

The field demonstration results vary greatly between characterization technologies. The number of man-hours required for the field demonstration varied from 18 hours in 2 days of field work for the $\mathrm{NaI}$ detector to 283 hours in 9 days of field work for the mobile LA-ICP/AES laboratory. Other technologies with low man-hour requirements for the field demonstration include the electret ion chamber (28), the Fidler detector (30), and the passive radon monitoring technology (31). In terms of man-hours, 
Fig. 1. Manhour Requirements for Field Demonstration Work

Passive Radon Monitoring

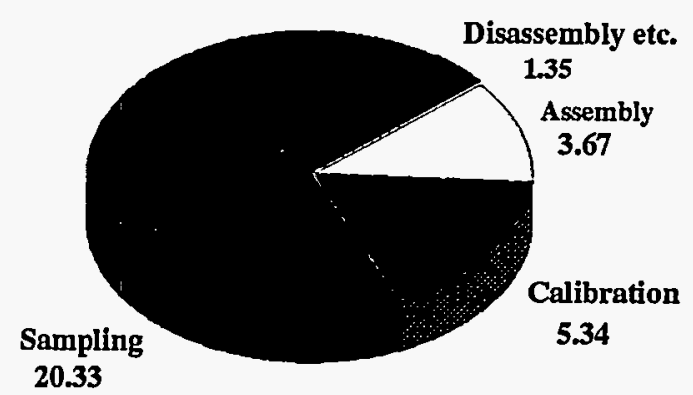

LRAD

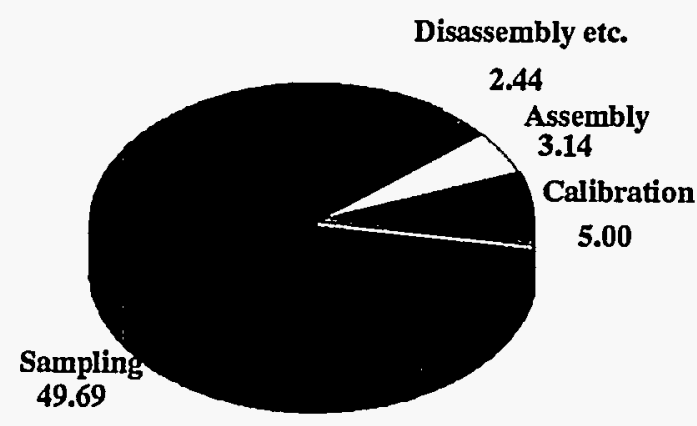

Electret Ion Chamber

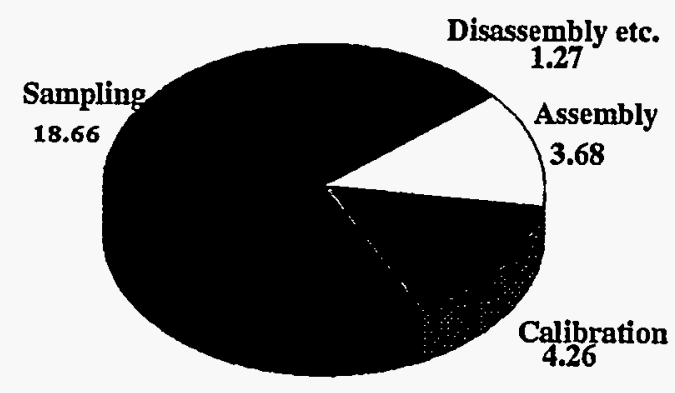

Fidler Device

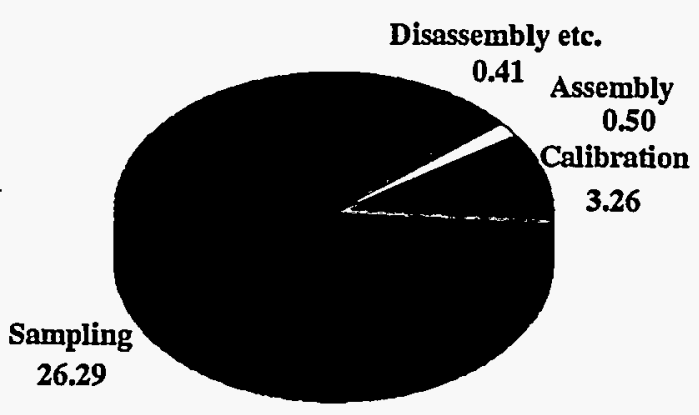


Fig. 1. (continued)

\section{Gamma Detector (High)}

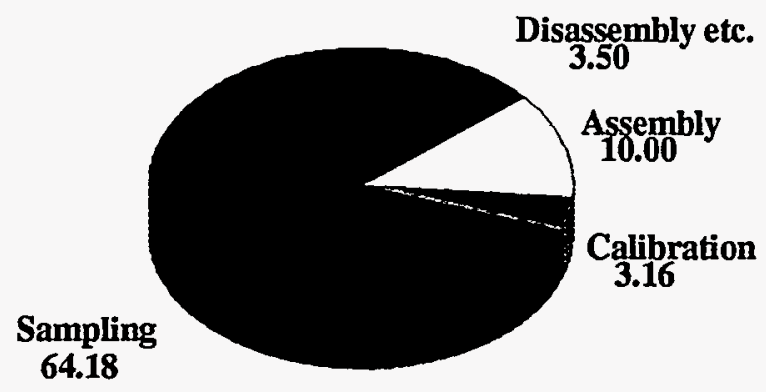

Sodium Iodide Detector

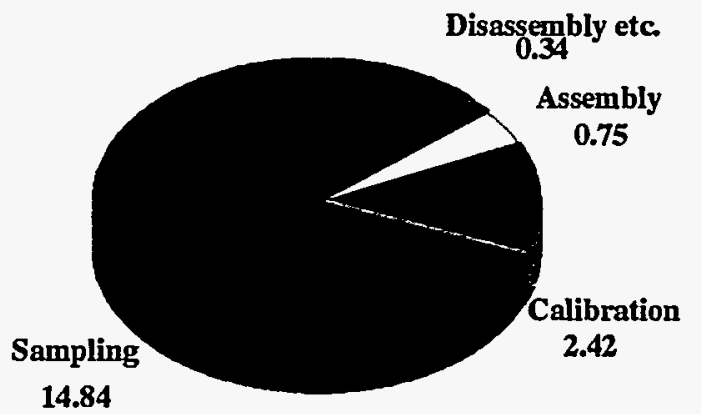


13

Fig. 1. (continued)

\section{Beta Scintillation}

Disassembly etc.

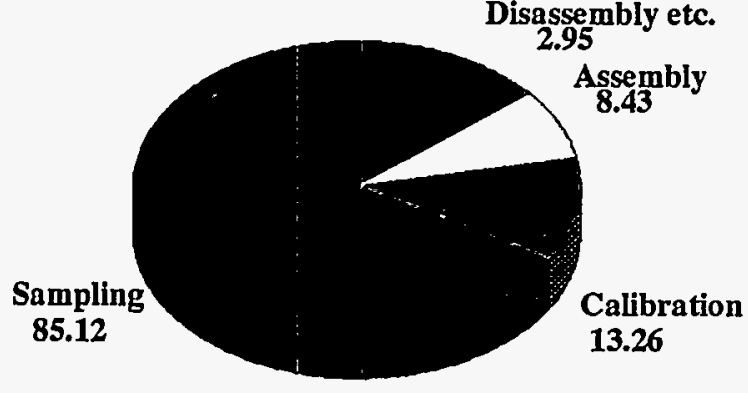

XIRF Detector

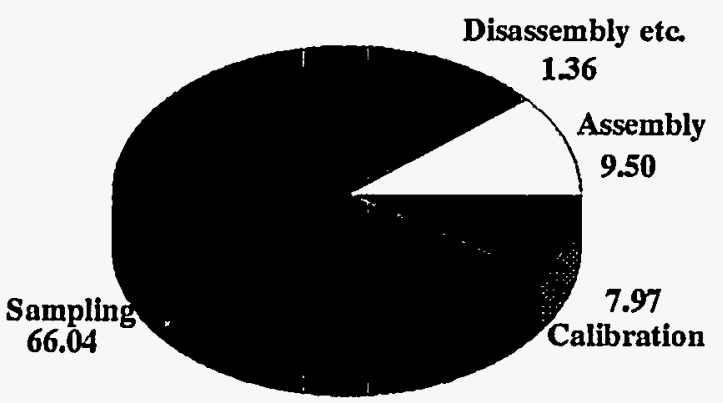

\section{LA-ICP-AES}

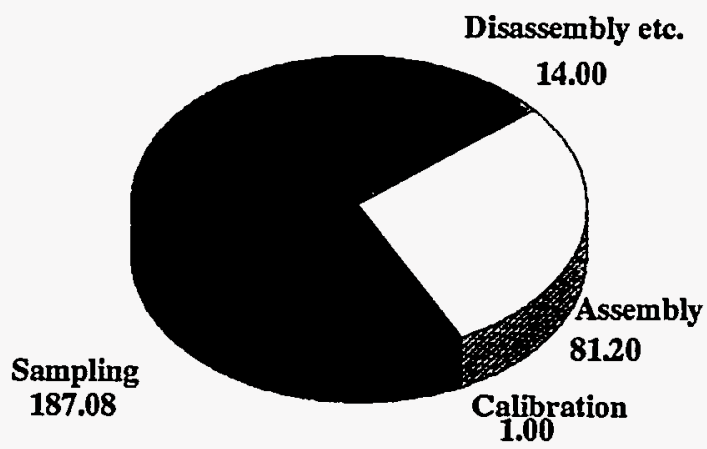

Gamma Detector (Low)

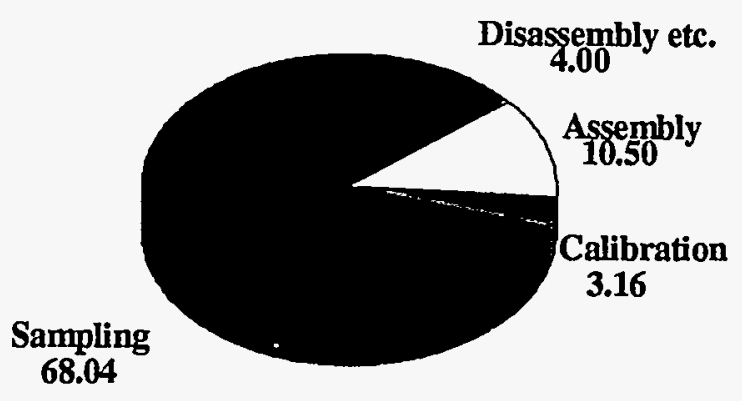


Fig. 2. Summary Results from the Field Demonstration

\section{Labor Cost}

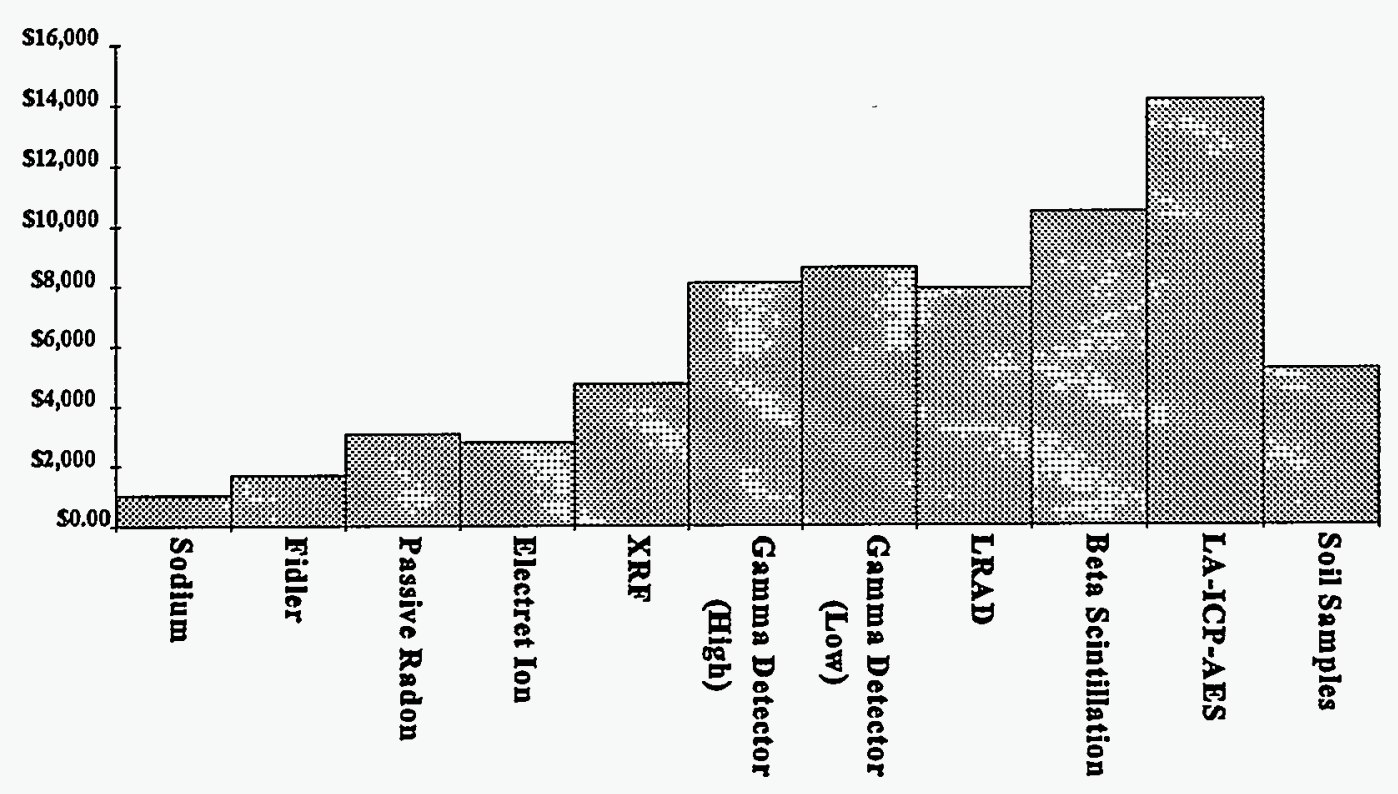

Total Cost

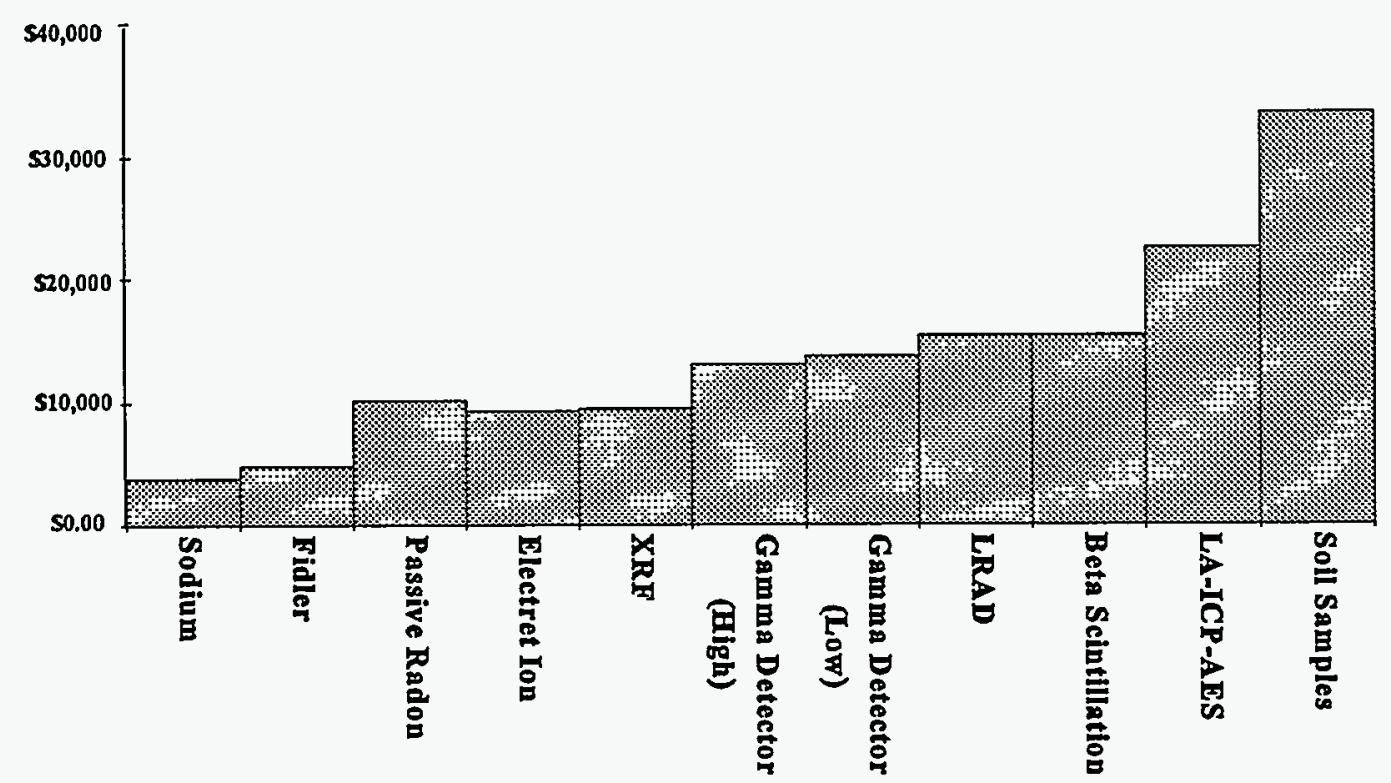


Fig. 2. (continued)

\section{Labor Cost/Sample}

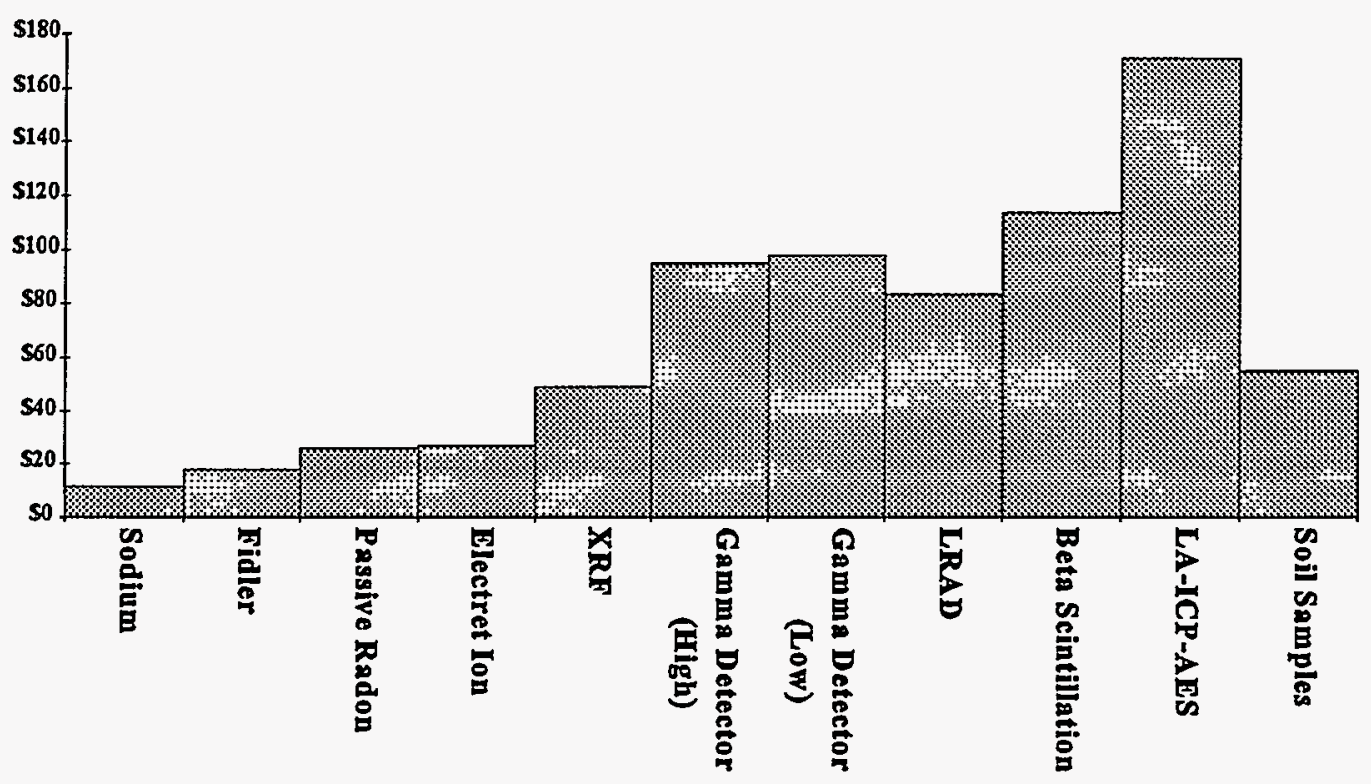

Total Cost/Sample

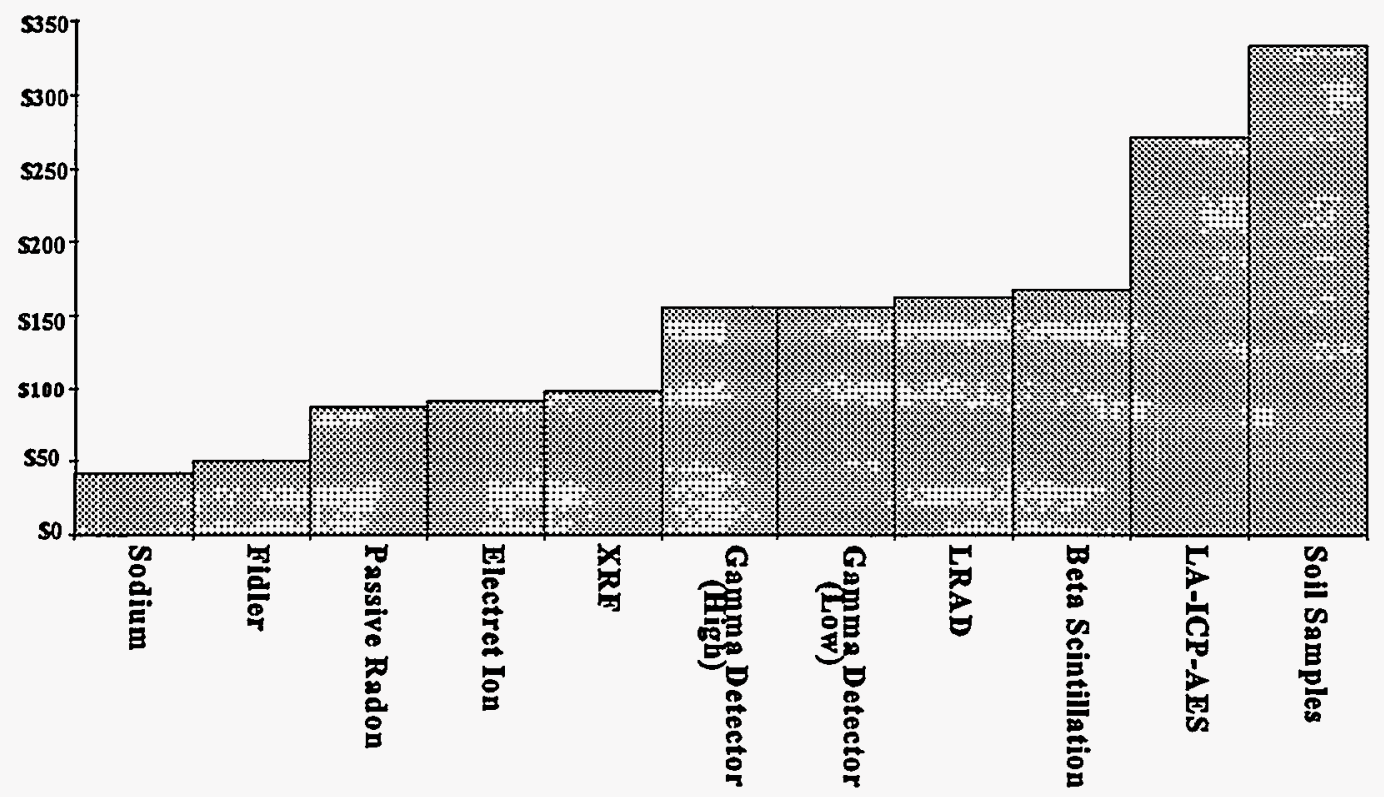


Fig. 2. (continued)

\section{Number of Days in Field}

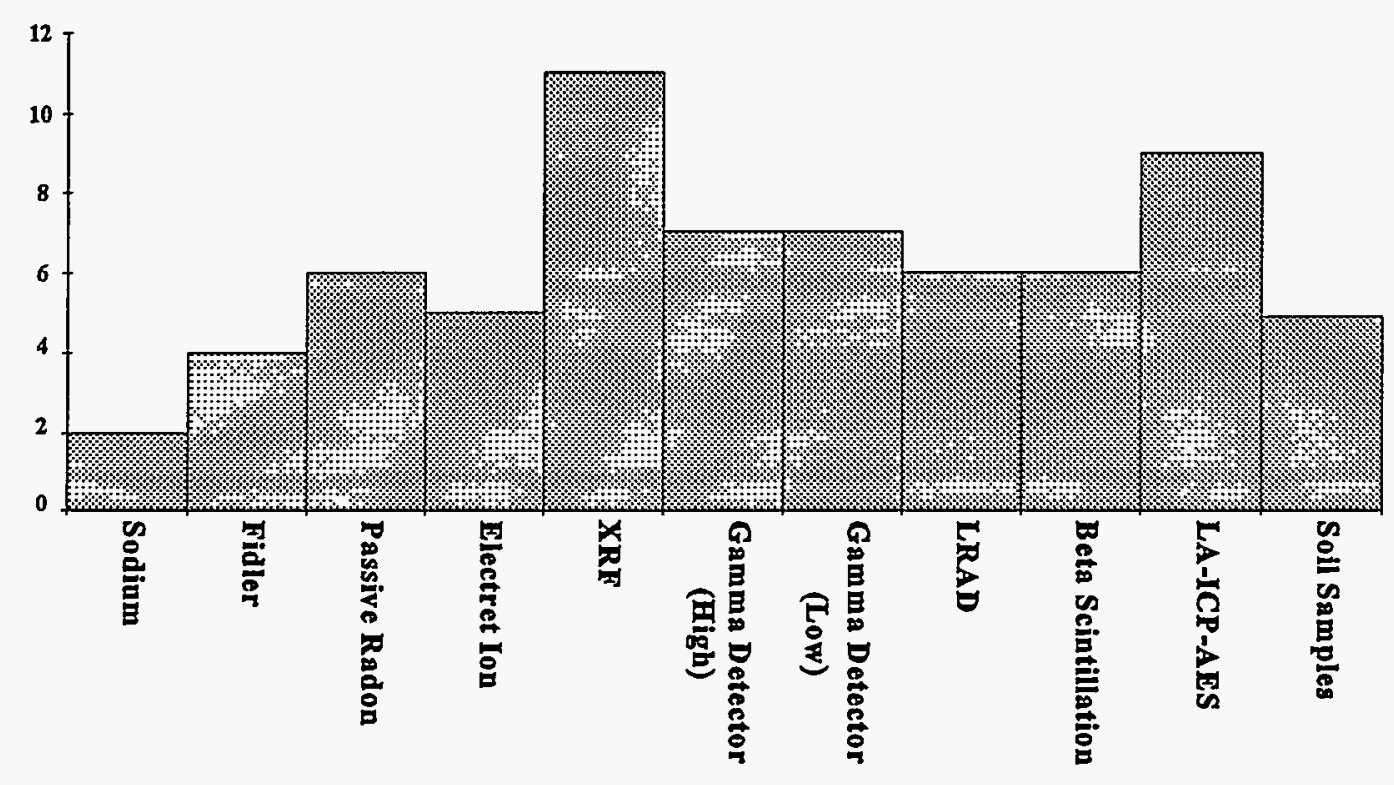

Man-Hours

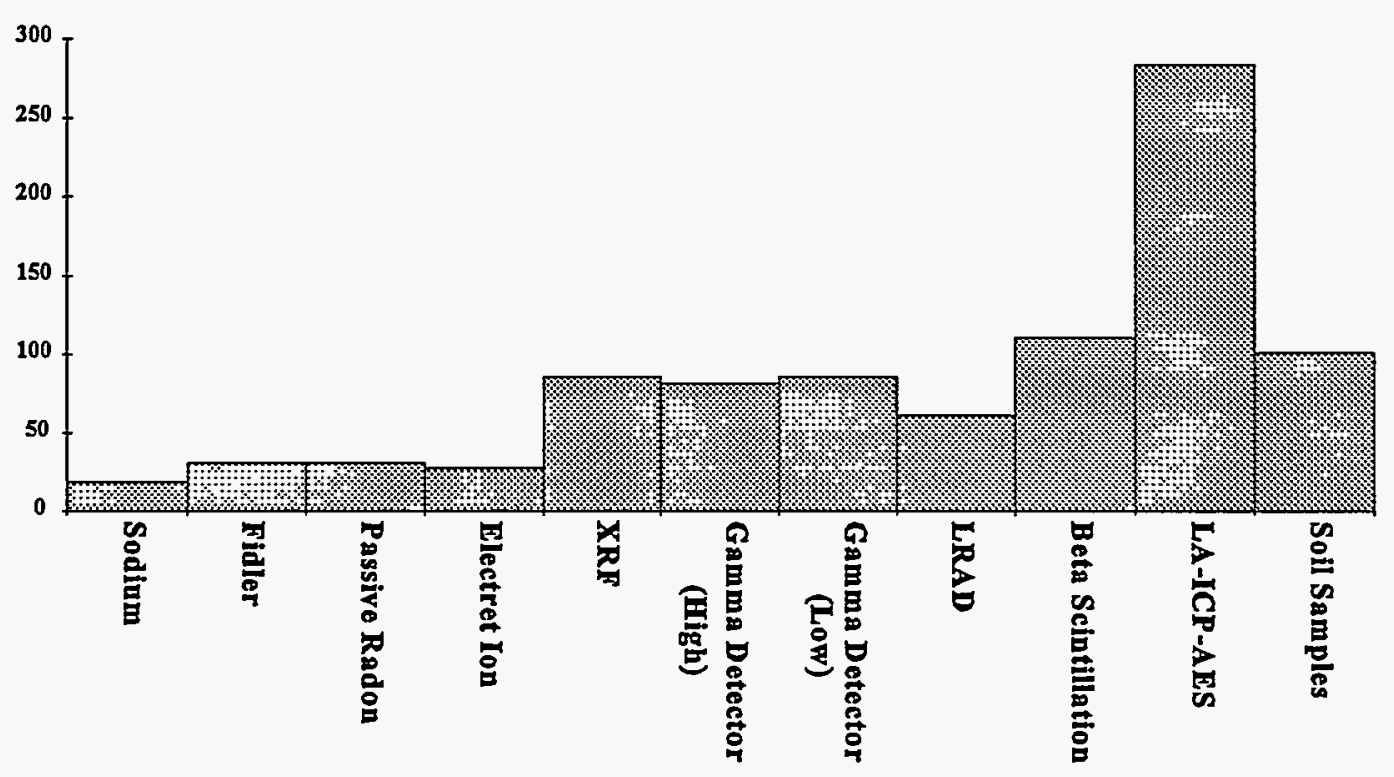


the PNL group operating the beta scintillation detector came closest to the maximum (LA-ICP/AES laboratory at 283 man-hours), requiring 110 man-hours. The number of man-hours for the mobile LAICP/AES laboratory is higher because four personnel are required to operate this technology, as compared to two personnel for the other technologies. In addition, the Ames laboratory crew operating the mobile laboratory had mechanical and operational difficulties during the field demonstration. Therefore, approximately 73 man-hours and 2 days in the field resulted in no data collection.

Note that while the mobile LA-ICP/AES laboratory required the most man-hours to conduct the demonstration, it resulted in the least number of field samples collected. With a total of 83 samples collected, data from 6 of the sample locations were not reported. The site characterization was canceled for the mobile laboratory after the collection of the 83 samples due to a malfunction of the laser equipment. Although the XRF detector required the most number of days to collect the field samples (11), the number of man-hours in the field for this technology ( 85 hours) was low compared to the other characterization technologies.

The number of field samples collected were used to calculate the labor cost per sample and the total cost per values for each characterization technology. However, the number of samples collected in the calibration beds and standards plots were strictly used for instrument calibration so that more accurate data at the 89 field sample locations could be collected. Therefore, even though the labor time to collect the calibration bed and standards plot samples were included in the labor cost calculations, the calibration bed and standards plot samples were not included in calculating the labor cost per sample and total cost per sample values for each technology.

The total labor costs, labor cost per sample, total costs, and total cost per sample for each technology to conduct the field demonstration are shown in Fig. 2. The total labor costs varied from $\$ 1,028$ for the $\mathrm{NaI}$ detector to $\$ 14,164$ for the mobile LA-ICP/AES laboratory. The labor cost per sample for the technologies varied from $\$ 12$ for the $\mathrm{NaI}$ detector to $\$ 171$ for the mobile laboratory. For the soil sampling and laboratory analysis scenario, the labor cost per sample value of $\$ 55$ is only for the labor time to collect the field samples and does not include any labor time for laboratory analysis. However, the ICP-MS analysis cost of $\$ 200$ per sample (Table 1) covers labor costs for laboratory analysis. The total costs associated with the field demonstration varied from $\$ 3,709$ for the NaI detector to $\$ 35,055$ for the soil sampling and laboratory analysis. The most economical technology to operate, based on the results of the field demonstration, was the $\mathrm{NaI}$ detector at $\$ 42$ per field sample, followed by the Fidler detector at $\$ 50$ per sample and the passive radon monitoring technology at $\$ 87$ per sample. The most expensive technology to operate was the soil sampling and laboratory analysis, with a cost of $\$ 340$ a sample, followed by the mobile LA-ICP/AES laboratory at $\$ 272$ per field sample and the beta scintillation detector at $\$ 167$ per sample.

The personnel labor rate has a major impact on a technology's performance in terms of cost for this field demonstration. In addition to the obvious effect of the personnel charge rate on the labor costs, the charge rate also affects the travel costs since employees must be paid to travel to and from the FERMCO site. This cost was included in the cost estimates since it would be included in an actual bid for characterization work. The total cost per sample values for the conventional characterization technologies (NaI, Fidler, and XRF detectors) are fairly low due to the fact that the FERMCO personnel operating these technologies reported a lower personnel charge rate. It is important to note that although the personnel operating the mobile LA-ICP/AES laboratory reported a low personnel charge rate, the number of personnel required to operate this technology was four, compared to two for the other 
technologies. Therefore, it is important to investigate the potential for training technicians (with lower charge rates) to operate the alternative technologies, thereby reducing the costs of operation and making them more cost competitive with the traditional characterization technologies.

\section{SUMMARY OF THE FIELD DEMONSTRATION}

This document summarizes each characterization technology's cost results based on its performance at the field demonstration at the Fernald site in the spring of 1994. The characterization technologies participating in the field demonstration include six alternative technologies developed and demonstrated by various members of the USID Characterization Group and three traditional detectors demonstrated by FERMCO personnel. In addition, standard soil core sampling and laboratory analyses were also conducted by FERMCO personnel as a baseline condition to compare cost and performance measures between the technologies. The final summary sheet, Table 2, summarizes the results of each technology's cost estimates based on field demonstration results. This table also provides the number of days and manhours spent in the field and the number of field samples collected by personnel operating each characterization technology.

The number of days required to collect the data varied considerably between the technologies, ranging from 2 days for the $\mathrm{NaI}$ detector to 11 days for the XRF detector. The number of man-hours required to conduct the field demonstration also had a wide range, from 18 hours for the NaI detector to 283 hours for the mobile LA-ICP/AES laboratory. It is important to note that certain characterization technologies were in the field a large number of days but with a low number of manhours. The number of manhours are important in determining the cost competitiveness of the technologies because the labor costs and personnel charge rates are key components in the total costs associated with operating the technologies. The labor costs shown in Table 2 are based strictly on the number of man-hours required to conduct the field demonstration and the charge rate of the technicians or scientists operating the characterization technology. In most cases, the labor costs are based on the time spent in the field to collect the data. However, with some technologies additional labor time was required at the end of the day to manipulate and process the data. The labor hours required to complete this task were included in the site characterization hours.

The labor cost per sample varied from $\$ 12$ per sample for the NaI detector to $\$ 171$ per sample for the mobile LA-ICP/AES laboratory. The wide variation in the labor costs are primarily a result of the number of man-hours spent in the field collecting the data and the number of personnel required in the field. Whereas most of the characterization technologies required 2 personnel in the field, the mobile LA-ICP/AES laboratory required 4 personnel, resulting in the technology which required the most number of man-hours to complete the field demonstration (283).

The total cost for the field demonstration includes the following costs associated with a site characterization: travel and transportation costs assuming the host site is $\mathbf{5 0 0}$ miles away from the technology operator, labor costs to perform the field demonstration, and miscellaneous costs associated with the operation of the technology, such as personnel protective equipment, fuel, and other equipment necessary to conduct the field demonstration. The results indicate the cheapest technology to operate is the NaI detector at a cost of $\$ 42$ per sample. As expected, the most expensive is soil sampling and laboratory analysis at a cost of $\$ 340$ per sample. As shown in Table 2, 5 of the characterization technologies cost less than $\$ 100$ per sample (NaI, Fidler, passive radon monitoring, electret ion chamber, 
Table 2. Summary of the Field Demonstration

\begin{tabular}{|c|c|c|c|c|c|c|c|}
\hline Technology & $\begin{array}{l}\text { Field } \\
\text { Days }\end{array}$ & Manhours & $\begin{array}{c}\text { Number of } \\
\text { Samples }\end{array}$ & Labor Cost & $\begin{array}{c}\text { Labor } \\
\text { Cost/Sample }\end{array}$ & Total Cost & Total Cost/Sample \\
\hline $\begin{array}{l}\text { Sodium-iodide }(\mathrm{NaI}) \\
\text { detector }\end{array}$ & 2 & 18 & 89 & $\$ 1,028$ & $\$ 12$ & $\$ 3,709$ & $\$ 42$ \\
\hline $\begin{array}{l}\text { Low-energy } \\
\text { scintillation detector } \\
\text { (Fidler) }\end{array}$ & 4 & 30 & 95 & $\$ 1,706$ & $\$ 18$ & $\$ 4,771$ & $\$ 50$ \\
\hline $\begin{array}{l}\text { Passive Radon } \\
\text { Monitoring }\end{array}$ & 6 & 31 & 117 & $\$ 3,069$ & $\$ 26$ & $\$ 10,131$ & $\$ 87$ \\
\hline $\begin{array}{l}\text { Electret Ion } \\
\text { Chamber }\end{array}$ & 5 & 28 & 102 & $\$ 2,787$ & $\$ 27$ & $\$ 9,337$ & $\$ 92$ \\
\hline $\begin{array}{l}\text { X-ray fluorescence } \\
\text { (XRF) detector }\end{array}$ & 11 & 85 & 97 & $\$ 4,753$ & $\$ 49$ & $\$ 9,588$ & $\$ 99$ \\
\hline $\begin{array}{l}\text { In Situ gamma } \\
\text { detector (high) }\end{array}$ & 7 & 81 & 85 & $\$ 8,084$ & $\$ 95$ & $\$ 13,183$ & $\$ 155$ \\
\hline $\begin{array}{l}\text { In Situ gamma } \\
\text { detector (low) }\end{array}$ & 7 & 86 & 88 & $\$ 8,570$ & $\$ 97$ & $\$ 13,669$ & $\$ 155$ \\
\hline $\begin{array}{l}\text { Long-range alpha } \\
\text { detector }\end{array}$ & 6 & 60 & $95^{-}$ & $\$ 7,926$ & $\$ 83$ & $\$ 15,366$ & $\$ 162$ \\
\hline $\begin{array}{l}\text { Beta Scintillation } \\
\text { Detector }\end{array}$ & 6 & 110 & 92 & $\$ 10,428$ & $\$ 113$ & $\$ 15,391$ & $\$ 167$ \\
\hline $\begin{array}{l}\text { LA-ICP/AES } \\
\text { laboratory }\end{array}$ & 9 & 283 & 83 & $\$ 14,164$ & $\$ 171$ & $\$ 22,540$ & $\$ 272$ \\
\hline $\begin{array}{l}\text { Soil Sampling \& } \\
\text { Laboratory Analysis }\end{array}$ & 5 & 101 & 103 & $\$ 5,656$ & $\$ 55$ & $\$ 35,055$ & $\$ 340$ \\
\hline
\end{tabular}


and the XRF detector). The in situ gamma, long-range alpha, and beta scintillation detectors fall in the range of $\$ 150$ to $\$ 200$ per sample based on the results of the field demonstration. The only alternative technology with a cost over $\$ 200$ per sample was the mobile LA-ICP/AES laboratory, at an estimated cost of $\$ 272$ per sample.

The characterization technologies demonstrated at the Fernald field demonstration are based on different scientific principles and are thereby unique in their ability to detect uranium-contaminated soil. The extent of contamination, location of contamination, the uranium form present in the soil, and weather conditions are a few of the factors that could affect the performance of a characterization technology. Therefore, it is difficult to directly compare these technologies since the type and scale of measurement differs for each technology, potentially leading to different data results for the same sample locations. For these reasons, it is important to recognize that each characterization technology is unique and performance cannot be based on cost alone.

\section{REFERENCES}

Field Demonstration Project Plan. Uranium-in-Soils Integrated Demonstration Program. May 1994. 
ORNL/TM-12985

\section{INTERNAL DISTRIBUTION}

$\begin{array}{ll}\text { 1. } & \text { M.R. Ally } \\ 2 . & \text { A.Q. Armstrong } \\ 3 . & \text { B.A. Berven } \\ 4 . & \text { N.H. Cutshall } \\ 5-8 . & \text { D.M. Douthat } \\ 9 . & \text { M.P. Elless } \\ \text { 10. } & \text { C.W. Francis } \\ 11 . & \text { S.Y. Lee } \\ 12 . & \text { A.P. Malinauskas } \\ 13 . & \text { C.W. McGinn } \\ 14 . & \text { D.B. Miller } \\ 15 . & \text { J.G. Pruett } \\ \text { 16. } & \text { C.C. Travis } \\ 17 . & \text { J.H. Wilson } \\ 18 . & \text { Central Research Library } \\ 19 . & \text { ORNL Y-12 Technical Library } \\ 20-21 . & \text { Laboratory Records Dept. } \\ 22 . & \text { Laboratory Records, RC } \\ 23 . & \text { ORNL Patent Office }\end{array}$

\section{EXTERNAL DISTRIBUTION}

24. M. Anderson, Ames Laboratory, Environmental Technology Development, 125 S. 3rd St. Sherman Building, Ames, IA 50010-6739

25. T.D. Anderson, U.S. Department of Energy, 19901 Germantown Road, Germantown, MD 20874-1290

26. S. Chamberlain, U.S. Department of Energy, 19901 Germantown Road, Germantown, MD 20874-1290

27. J.C. Cunnane, Argonne National Laboratory, 9700 South Cass Avenue, Argonne, IL 60439

28. D. Gerrick, FERMCO, P.O. Box 398704, Cincinnati, Ohio 45239-8704

29. D. Herman, FERMCO, P.O. Box 398704, Cincinnati, Ohio 45239-8704

30-34. P.G. Kaplan, Division 6312, Sandia National Laboratories, Albuquerque, NM 87185-1326

35. D. Layton, Lawrence Livermore National Laboratory, P.O. Box 5507, L-453, Livermore, CA 94550

36. D. MacArthur, Los Alamos National Laboratory, MS J562, Los Alamos, NM 87545

37. M. Malone, U.S. Department of Energy, 19901 Germantown Road, Germantown, MD 20874-1290

38. J. Mohiuddin, U.S. Department of Energy, 19901 Germantown Road, Germantown, MD 20874-1290

39. J.O. Moore, U.S. Department of Energy, Oak Ridge Operations, 3 Main Street, Oak Ridge, TN 37831

40. D. Morris, INC-II Actinide Team, MS C345, Los Alamos National Laboratory, Los Alamos, NM 87545

41-43. K. Nuhfer, FERMCO, P.O. Box 398704, MS-81-2, Cincinnati, Ohio 45239-8704 